\title{
How Social Movements Do Culture
}

\author{
William G. Roy
}

Published online: 26 February 2010

(C) The Author(s) 2010. This article is published with open access at Springerlink.com

\begin{abstract}
While much social science literature has analyzed the cultural bases of social movement, activity, and the content of cultural production by social movements, relatively little has been written about the concrete social relations within which social movements do culture. This paper addresses the issue of what social movements are doing when they produce culture. Four dimensions of social relations within which culture is enacted are identified: the division of labor, the relations of power, tuning in, and embeddedness. A contrast between the how the People's Songsters Movement of the 1930s and 1940s and the Civil Rights Movement of the 1960s used American folk music illustrates how variation in these dimensions affects the effects that cultural production had on social movement outcomes.
\end{abstract}

Keywords Social movements · Culture · Modes of relationships · Civil Rights Movement

"When I hear music, I fear no danger. I am invulnerable.

I see no foe. I am related to the earliest times, and to the latest."

Henry David Thoreau

The power of music has long been celebrated by philosophers, poets, statesmen and activists. Music has the power to seduce, inspire, soothe, and fortify. We all know that.

What do social movements do? They protest, plea, organize, recruit, petition, demonstrate, meet, debate, strike, and express. As collective agents of expression, like other collectivities, they do art, literature, music, drama, and other creative endeavors. Some authors have even suggested that their cultural activities are more enduring and historically important than their political achievements (Eyerman and Jamison 1998). The most common question about the cultural activities of social movements probes meaning: How are cultural expressions motivated by activists and interpreted by audiences? Insofar as

The paper has benefited from the constructive and insightful comments of Jacqueline Adams and Violaine Roussel. Permission to publish this article in English was granted by Presses Universitaires de Vincennes.

W. G. Roy $(\bowtie)$

Department of Sociology, University of California, Los Angeles, Los Angeles, CA 90095-1551, USA

e-mail: billroy@soc.ucla.edu 
social movements are defined in terms of their goals and demands, cultural objects are critical to fathom movements' mindsets, ideologies, and cultural resonances. But, content is only one dimension of how social movements do culture. Thus, the central issue of this paper is how sociologists studying social movements study culture. The argument is simple: As important as content of cultural forms is, the effects of art, music, drama, literature, etc. achieved by social movements depend at least as much on the social relations within which culture is embedded. We need to move beyond attending to the content of art, music, drama, literature, etc. to examine how people relate to each other while doing music, drama, literature, etc. We need to recognize that the social relationship by which one person or group has a monopoly on creativity, which they disperse to audiences, is only one kind of social relationship for culture. The claim here is that many people doing art, doing music, doing drama, doing literature, not just consuming it, is an extraordinarily powerful mode for both solidifying commitment to social movements and for helping them achieve their goals.

I will illustrate the argument with a comparison of two social movements that selfconsciously used American folk music but with very different results. In contrast to Europe, where the genre of folk music was invented as part of the nationalizing projects of the late nineteenth century (Cohen 2002), folk music in the US was used by left-wing groups. Like recent social movements in France (Waters 2003), social movements in America have used music and other cultural forms to simultaneously express distinctive identity and cultural commonality. The communist-led movement of the 1930s and 1940s developed the most extensive and elaborate cultural infrastructure of any movement in American history, with influence in every aesthetic realm from fine literature to Hollywood (Denning 1996). They successfully catapulted American folk music from an esoteric interest of academics and antiquarians into a genre of popular music. But, they failed to reach their target audience - the working class. One major reason is that they never transcended the conventional social relationship that prevails in western culture, that of performer and audience, even though they were to create a culture of participatory performance. In contrast, the Civil Rights Movement of the 1950s and 1960s is well known as one of the most musical movements in American history. For a brief period at least, music fortified the movement, wielding solidarity among the participants, and, with music that had strikingly thin political content, stirred the public imagination. The more powerful role that music played in the Civil Rights Movement is explained less by the music itself, much of which was inherited from the Old Left, than by the social relationship within which it was done. For the Civil Rights Movement, music was less a matter of a performer singing for an audience than part of the collective action itself. At the lunch counter, on the picket line, on the bus rides, and in jail, they made music collectively. Unless we attend to the social relations in which people are doing culture, we will be unable to explain the different effects that music had for these two movements.

\section{Modes of Relationships Between Culture and Social Movements}

Sociology has conceptualized several ways that social movements relate to culture.

1. Art as a social movement: Sometimes artists organize as artists, musicians as musicians, or writers as writers, not just in pursuit of their own self interests, as when they unionize but toward larger social or political goals. The Harlem Renaissance of the 1920s exemplified this type of movement when such luminaries as Langston Hughes, James Weldon Johnson, W. E. B. DuBois, Louis Armstrong, and Billie Holiday transformed the face of American letters and music (Bell 1975; Floyd 1990). Artists often feel obliged to join 
together as artists to use their talents on behalf of movements for justice and change. Thus, artists against the war in Iraq have formed an Artist Network that supports the larger anti-war effort. Roussel has investigated the trajectories by which artists become active and cope with conflicting pressures (Roussel 2007).

2. Social movement dynamics in art worlds: Apart from the overt politically engaged artistic projects like the Harlem Renaissance, Howard Becker has pointed out that all art is a collective activity that shares characteristics with social movements. Art worlds coalesce around networks, mobilize resources, selectively defy conventions, wax and wane, much as social movements (Becker 1982; Zolberg and Cherbo 1997). Innovation tends to appear at the margins of art worlds and diffuse in manner of new ideologies. Artists cluster around insurgent schools to challenge orthodoxies, often based in new organizational forms. Thus, impressionism became a major art form when a new distribution system based on critics, dealers, and small exhibitions challenged the Academy system and created a very different art world (White and White 1993). Even when change is initiated by elites, it often takes the form of innovating new organizational forms that diffuse to other locales. In the US, high art and music became differentiated from popular art and music through the institutionalization of the elitesponsored non-profit corporation. Such organizations as the Boston Museum of Fine Arts or the Boston Symphony Orchestra were able to liberate themselves from dependence on commercial success by relying on elite subsidies, making it possible to sustain refined culture (DiMaggio 1982a, b). The art world that the organizational form enabled then spread to other cities, much as a movement spreads.

3. Cultural analysis of music, literature, and drama in social movement art: By far the most common mode of analysis is cultural analysis of the content of art, music, literature, and drama. Art, music, literature, or drama is treated merely as a vehicle to communicate content, like speeches, newsletters, protest demands, petitions, or interviews. Hermeneutic, semiotic, or interpretative analysis is applied to understand how social movements make meaning or connect to the meaning sets of constituencies. As Swidler describes the cultural role of social movements: "Even without conscious efforts at publicity, one of the most important effects social movements have is publicly enacting images that confound existing cultural codings" (Swidler 1995, p. 33).

The model typically underlying the role of culture in social movements is that social movements succeed in reaching goals by adding members: members decide to join and participate on the basis of alignment between their meaning systems and those of the social movement. So a social movement can grow and thus succeed by articulating meanings close to potential constituents or by doing the cultural work of converting potential constituents to their ways of seeing the world. As a close parallel to the way that some religious organizations grow, we might call this the evangelical model of movement building. What becomes sociologically at stake in this perspective is what content of ideas, symbols, ideologies, narratives, and in recent scholarship, frames most effectively converts recruits into apostles. The recruit is assumed to be mainly a culture processor, taking in ideas, symbols, ideologies, narratives and frames, and responding with support, indifference, or hostility on the basis of a pre-existing mental state. The typical event in this process is the culture-driven decision. ${ }^{1}$ And that culturally driven decision to participate or not is often prior to and analytically divorced from

\footnotetext{
${ }^{1}$ While there is no reason why sociologists could not study iterative processes by which previous cultural work changes social movements or recruits, setting the stage for later culturally informed decisions, this is rarely done. Though see Pedriana and Stryker (1997) for an effective analysis of how discourse at one point in time can influence later discursive interaction.
} 
the recruits' actual participation in the social movement itself. Though eschewing the autonomous decision-maker of rational choice theory, cultural theory (understood as a system of mental frames) too often substitutes a culturally informed decision-maker. Both assume an autonomous actor soaking up input, digesting it internally, and outputting a decision. Missing is the kind of social relationship within which culture is performed. As important as the content of culture is, the same words, symbols, images, narratives, and frames can have very different effects depending on the qualities of relationship within which it occurs. This is what a relational approach can bring to the table.

The relational approach focuses on the qualities of interaction itself. It is the sound of two hands clapping, which can never be reduced to the qualities of each hand separately. For example, equality is a relational quality, irreducible to the amount of goodies held by either party, but found only in the relationship of parties to each other. Equality between two actors can be achieved if both are wealthy or both poor. It depends on the wealth of neither actor as individual but only how they relate to each other. A relational approach to social movements can take at least three forms. The most common is the network approach (Snow et al. 1980; Klandermans and Oegema 1987; Marwell et al. 1988; Gould 1995; Diani and McAdam 2003; Andrews and Biggs 2006). Here, the content of cultural work is refracted through the structure of relationships within which a recruit is embedded. Such factors as the unanimity of influence, the number of people that influence a recruit, the extent to which interaction partners interact with each other all have an effect on how people make decisions. A second relational approach focuses on various enduring qualities of interaction among people. Trust, emotional bonds, and solidarity among people lubricate cultural work making potential recruits more open to influence (Stepan-Norris and Zeitlin 1989; Jasper 1998; Tilly 2005). A third approach, which is emphasized here, focuses on the social dynamics of the interaction as it happens, examining how the nature of what is going on at the time of the interaction affects the consequences of doing culture. For example, the social relationships in a classical music performance are shaped by such factors as the architecture, physical layout, performance practices, norms of audience comportment, and the division of labor among composer, performer, conductor, and audience (Small 1998). Similarly, DeNora (2000) describes how the activities that people do to music shapes not only the meaning of the music but the activities being done, whether solitary listening, aerobics, shopping, making love, or raving. The social relations interact with the sonic qualities to shape the experience, as music affords or lends itself to different ways of experiencing.

For the purposes of this paper, we can identify four dimensions of the social relationships within which culture is enacted:

1. The division of labor within which culture is enacted: For western music, labor is divided among composer, performer, listener, and interpreter, though other societies have very different divisions of labor (Feld 1984). Likewise Graffiti, especially when it is part of gang activity, typically is embedded in a very different relationship of artist and audience from conventional art. Some forms of street theater attempt to break down the wall between performer and audience by enticing bystanders to participate in the unfolding drama. When we acknowledge that "Music is not a thing at all but an activity, something that people do" (Cohen 2002, p. 2), the division of labor becomes very important. Western culture distinguishes between composition, performance, distribution, and reception, even when individuals do more than one job. There are of course exceptions. Jazz blurs the line between composition and performance. Congregational singing blurs the line between performance and reception. Other societies do not make these distinctions. Among the Suya of Brazil, there are distinctions between composer, 
performer, and audience. Music is led by village elders for rituals in which men collectively improvise on known musical themes (Seeger 2004). The division of labor defines the bundle of tasks that people perform when participating in the doing of art or music. Merely viewing or only listening calls for a much lower degree of participation than more active tasks and thus is less involving. This is especially true when the involvement is collective. As Becker argues, all the arts are collective, even those, such as painting or poetry, often considered solitary (Becker 1982). The division of labor in that collective effort and the role that people play in the division of labor is a major factor in the effects that the arts can have, quite apart from their content.

2. Power: Whatever the division of labor among people doing culture, there is variation in the power structure that describes the relative distribution of influence among different actors within art worlds. In classical music, for example, music directors select the repertoire for programs, composers dictate the notes played, conductors shape how the notes are played, and listeners influence trends through their choices of patronage. Similarly, artists, patrons, critics, brokers, and consumers differ in their relative power in different societies and different kinds of art. To some extent, the distribution of power is shaped by the division of labor. Separating the composer from the performer necessarily gives the composer considerable power. The musical score becomes a device by which the composer restricts the power of the performer to shape what is performed. When the performer is separated from the audience, any power the audience might wield is generally negative, their choices a selective mechanism that can reinforce some composers, pieces, and performers over others. The operation of power in social movements is important for the role of art not only in terms of the content, but also the form. Centralized movements make decisions about culture at the top, tending to adopt forms that maintain control. Leaders in centralized movements generally prefer to control the messages of cultural production and thus to prefer forms in which messages can be monitored. Decentralized movements allow a greater proliferation of message and permit forms of music in which the collective experience is more important than the message.

3. Tuning in: Schütz (1964) has described how music has the ability to synchronize people's consciousness into a sense of sharing that transcends the meaning it might have for any solitary listener. McNeill has argued that the synchronization of drilling, chanting, and singing fortifies collective efforts, including war (McNeill 1995). While auditory media like music, poetry, and chanting have obvious qualities of tuning in because they are set in time, visual arts also vary in the extent to which people experience them collectively or individually. For example, Chicano activists have selfconsciously created murals as group projects to foster solidarity (Reed 2005). Many accounts have described how the Chinese Cultural Revolution in the late 1960s was fanned by the crowds which gathered around poster walls. Schütz describes tuning in as a synchronization of inner time, 'the experience of 'We,' which is at the foundation of all communication" (Schütz 1964, p. 173). It can take the form of mutual gaze, conversation, ritual participation, or music. This is a variable concept, not a dichotomy; there can be shallow or deep tuning in that can foster trivial or consequential bonds. Singing a duet together bonds more tightly than hearing canned music in a store. For social movements, joining arms and singing creates more solidarity, more a sense of "We" than attending a concert together, no matter how effective the performance, just as congregational singing is more likely to foster devotion than a choral anthem.

Tuning in is one of the major mechanisms by which the content of artistic expression affects recruitment and commitment. The impact of a message depends not only on whether 
it resonates with a receiver's values and world view, but also on the circumstances under which it is communicated, especially the presence of others. Messages are more likely to have impact when the sender and receiver are tuned in through what Schütz calls precommunicative interaction, by which he means intercourse that precedes communication through mutual orientation toward each other. It is the social achievement by which people are on the same page, by which they can react when interacted with. Music is one of the strongest means for tuning in, especially making music together (Schütz 1964; McNeill 1995; Frith 1996). To persuade, messages must be consistent with receivers' prior values and world view. But, they are much more powerful when refracted through tuning in. It is tuning in that gives music, not just lyrics, its power. This is why states have national anthems, religions have hymns, and social movements have protest songs.

4. Embeddedness: Western society is distinctive in the extent to which it has framed culture as putatively pure form, denigrating art, music, literature, and drama that is supposedly compromised by "using" culture for non-artistic purposes. Culture is considered most aesthetic when it is the most pure and aesthetically compromised when it is intended for political, commercial, or other instrumental purposes. Comparative and historical studies have shown the peculiarity of the quest for pure culture. Other societies embed the arts in a variety of social forms-religion, work, political ritual, family, etc. (Lomax 1962; Small 1998; Feld 1984; Seeger 2004; Bohlman 1999; Gioia 2006; Taylor 2007). Similarly, historians and other scholars have documented how the conception of pure art or music autonomous from "society" is itself a historical development that emerged from a set of very particular circumstances. The exaltation of "pure" art as a separate sphere of action is an achievement to be explained more than it is an immanent aesthetic to automatically be defended against encroachment by society (Zolberg 1990; DeNora 1995; Citron 2000; Weber 1999). Social scientists are moving beyond the simple issue of whether "pure" culture is possible to investigate the relation between cultural and other social relations by studying what people are doing when they do culture. This is not a question of motivation or intention. Even when people understand themselves as doing pure culture, they are doing other things. Small, for example, has ethnographically described how the classical music concert is a site of displaying and reproducing middle class respectability (1998). Other studies more explicitly have investigated the relationship between cultural objects and religion, politics, sports, relaxing, making love, education, and of course social movements. While many of these studies focus on the content, others have analyzed how the culture is embedded in social relations (Zolberg 1990; Reed 2005; Berezin 1994; Du Gay 1997; Leblanc 1999; DeNora 2002; Martin 2004; Ikegami 2005; Rosenthal and Flacks 2009). Analyzing the embeddedness of culture means suspending the distinction between pure and pragmatic culture or between aesthetic and social dimensions to focus on what people are doing when they are doing culture.

\section{Music as Propaganda Versus Music in Collective Action}

The use of music by the Communist-inspired Left of the 1930s and 40s, often called the People's Songsters, and by the American Civil Rights Movement in the 1960s offers a vivid contrast of the social relationships within which culture can be done. Both adopted American folk music as an explicit cultural project but embedded it in very different types of social relationships with very different effects. The Old Left used music as a weapon of 
propaganda, establishing a formidable cultural infrastructure to expound the ideology they wanted the working class to embrace. While they succeeded in introducing the genre of folk music to American popular music, they failed to reach across the social boundaries they hoped folk music would bridge. In contrast, the Civil Rights Movement used music within collective action itself, singing freedom songs as they gathered, marched, rode busses, and endured jail. Abandoning conventional distinctions between performer and audience, content and form, with relative nonchalance about the political content of their music, their music helped bridge one of the most intractable social boundaries of American society, that of race.

Although the American Communist Party in the first half of the twentieth century is best known for heavy-handed political economy and a strongly materialist version of MarxistLeninism, as the leading force in the American left during the 1930s and 1940s, it developed an elaborate cultural infrastructure that touched on all media of cultural expression (Denning 1996.) Many of America's most respected literary figures such as Langston Hughes, John Dos Passos, Malcolm Cowley, and Richard Wright were active in the left and belonged to organizations affiliated with the party. Other party organizations produced drama, art, and criticism on a large scale. Beginning in the $1920 \mathrm{~s}$, politically engaged musicians established foreign language choruses for workers and a Composers' League that included such distinguished contributors as Marc Blitzstein, Aaron Copeland, Charles Seeger, and the recently immigrated Hanns Eisler. After discovering that politically motivated modern classical music did not appeal to workers, largely at the instigation of Charles Seeger, they took on American folk music as "the people's music." Folk music was more appealing than other vernacular genres for several reasons. Popular commercial music reeked of bourgeois culture; country music and blues were associated with particular groups, namely rural whites and rural blacks, and most important, "the folk" could be thought of as "the people." As one of the few politically engaged predominantly white organizations that self-consciously reached out to African Americans, the people's song movement explicitly defined folk music to include black and white music.

For the rest of the paper, I want to contrast how the Communist-inspired movement of the 1930s and 1940s and the Civil Rights Movement of the 1950s and 1960s each used music. The social relations within which culture was enacted helps explain the differential effect that the People's Songsters had on the movement and the broader society, why they succeeded more at making folk music a well known form of popular music than bringing together the broad range of people included in the "folk" and why the Civil Rights Movement was able to forge a racially diverse movement that served as a model for subsequent movements to emulate. I will organize the discussion around the four dimensions of social relationships within which culture is enacted, as discussed above. Some of the contrasts are over-drawn here for reasons of brevity.

1. The division of labor within which culture is enacted: The People's Songsters movement adopted the conventional composer/performer/audience model, while the Civil Rights Movement assumed a song-leader/group model. Although the earliest communist-inspired music was found in popular choruses, mostly non-English, the composers, song collectors, and performers who promoted folk music in the 1930s and 1940s tended to fall back into a performance mode. Music was taken to the people in union meetings, urban coffee houses, night clubs, concerts both large and small, and rent parties needed to pay the rent of movement musicians. To be sure, they did not foster conventional quiescence of classical music concerts. One of the reasons they embraced folk music was so that audiences could participate. The best-known leftist singing group of that period, the Almanacs, was self-consciously participatory. The 
group's bass, Lee Hays, had come from the folk-music-rich Appalachian region where he honed the skills of song leading. He found an enthusiastic ally in the movement's most visible advocate, Pete Seeger. The Almanac singers intentionally refrained from becoming too professional, even to the point of abstaining from rehearsals and allowing participants of modest talent to participate.

Prior to that time, American folk music had been known mainly to academics and antiquarians. The "folk" in rural America who did the music that the academics labeled folk music did not understand their music to be folk music and did not make any distinction between inherited songs learned orally and commercial music learned from sheet music or the newly available radios many of them owned. Music that the academics labeled folk music was occasionally introduced to urban dwellers by rural musicians packaged as quaint, urban interpreters such as poet Carl Sandburg or concert versions performed in classical style. It was almost always performed by individuals or occasionally by duos. The leftist movement invented the urban folk singing ensemble with groups such as the Almanacs and the commercially successful Weavers, typically quartets with accompanying guitar, banjo, string bass, and sometimes, a mandolin. It was hoped that the ensemble format would encourage the audience to sing along, to make a concert a participatory experience. They even invented a new concert format, the hootenanny, an occasion where a variety of musicians could perform, with audience participation highly encouraged.

But, they failed to foster the singing movement they had hoped for. Even though activists wholeheartedly embraced the music and energetically participated in musical activities, the broader movement, especially the unions, did not become a musical union. Some movements produced songbooks, and some union meetings invited the Almanacs or other performers to perform, but music-making was more performative than participatory. The main problem was that the social roots of the music promoters conflicted with that of the workers. "Folk music" almost always refers to someone else's music. The people who indigenously do the music do not call it folk music, and those who do call it folk music are rarely very folk-like. "Folk music" typically refers to rural, agrarian, unlettered, unrefined music that is embraced by urban, educated, sophisticated observers. The activists who adopted folk music as the music of the people were mostly college educated, either white Anglo-Saxon Protestants or second generation European Jewish immigrants sincerely motivated to reach across the cultural divide. However, the working class, mostly white, often upwardly mobile workers were unresponsive. Their music was more likely to be the popular commercial music of Benny Goodman than the politically charged folk music of the Almanacs. As Almanac lead singer Pete Seeger recalled, "We were convinced that the revival of interest in folk music would come through the trade unions... How our theories went astray! Most union leaders could not see any connection between music and pork chops" (Seeger 1992, p. 26). It was not just a matter of culture $v$ s material interests. After a union performance in which the Almanacs dressed casually in order to connect more easily to the workers, the union members were offended at the lack of respect. They attended union meetings in coats and ties and expected performers to look their best.

The conventional composer/performer/audience division of labor was also reinforced by the organizational infrastructure developed by party members and sympathizers. The Communist Party from its earliest days self-consciously used culture as a weapon in the class struggle, creating art, literature, and music for, about, and sometimes, by the working class. In doing so, its creative practitioners also created culture by and for themselves, many of whom were not working class. Beginning in the 1920s, they were especially active in literature, reflecting the high culture orientation of many participants. "John Reed Clubs" 
named after the renowned communist journalist who emigrated to the Soviet Union, were created in many cities. The organizational infrastructure of left-wing folk music reached its peak after World War II, when the Communist Party was bearing up under assault from McCarthyism and expulsion from labor unions. At no point before or since has the organized left had such a significant presence in the musical culture of the nation. People's Songs, Inc. (PSI) drew together progressive musicians from the party fringes, New Deal activists, unions, and college campuses. By publishing books and magazines, sponsoring events, creating forums for interaction, and linking to other producers and distributors of left-wing music, they gave folk music a greater presence both in the media and movement at large. While American folk music had been given a radical tinge during the era of the Popular Front and the Almanacs, it was indelibly stamped as pink in the PSI era. Its musicians included many who are now considered folk legends - its inspirational leader, Pete Seeger, its icon of African American heritage, Huddie Ledbetter, its conscience of authenticity Woody Guthrie, and its storehouse of talent including Josh White, Brownie McGhee, Burl Ives, Tom Glazer, and Oscar Brand.

The division of labor in making music for the Civil Rights Movement dissolved the distinction between composer, performer, and audience. Meetings were modeled after the template of the black church where members were accustomed to congregational singing. While some major events such as the celebrated 1963 March on Washington followed a conventional performer/audience model, most of the collective action events in the movement had no single presider. Sit-ins, picketing, bus riding, marching, and the like involved organized crowds. So, the primary division of labor in the music was the leader and group, a well-known relationship in black communities, one that was further refined during the course of the movement. The Highlander School in Monteagle, Tennessee, a crucial training ground for movement activists, had regular workshops to train song leaders, share songs, and integrate music into the collective action. Many SNCC (Student Nonviolent Coordinating Committee) and CORE organizers in small towns were trained song leaders and many SCLC activists were ministers.

2. Power: The vanguard strategy of the Old Left manifested itself in a hierarchical party structure, contrasted with the leadership and empowerment orientation by which the Civil Rights Movement did culture. Though the artists and musicians associated with the party exercised considerable autonomy from the formal hierarchy overseen by the Cultural Division, the party did authorize the broad parameters of cultural form and content. Most importantly, the party inculcated in them the use of culture as a propaganda weapon (Lieberman 1995). A vanguard is a group that takes responsibility for educating masses. Under party guidance, culture is a means to communicate its understanding of truth. So, the Almanac Singers, who were hardly Party stalwarts, reversed their earlier anti-war lyrics after Hitler invaded the Soviet Union, parroting the party's fresh pro-Roosevelt belligerency. As educated urbanites, the institutional form they knew to achieve anything was to form an organization, elect officers, develop a program of activities, put out a newsletter, forge links with other organizations, and mobilize a constituency. With the Communist party as the major leftist organization in the country during the 1930 s, even those not initially affiliated would gravitate in that direction. When People's Songs, Inc. was established after World War II, they found an office in a building with other party-related organizations, hired a young party member as executive director, issued a newsletter containing tips on how to run a hootenanny along with politically engaged songs, and worked to find venues for radical performers. It was not top down in the sense of fealty to the party, which was at best indifferent to 
their activities. ${ }^{2}$ But, it was hierarchical in the sense that they assumed that the goal of the movement was to take their message to the less enlightened masses through the strategy of national organizations headquartered in the nation's cultural capital, New York City.

In contrast, the Civil Rights Movement was always highly decentralized, both organizationally and culturally. Song leaders were accountable only to other organizers. They were trained at transitory events such as workshops at the Highlander School and communicated with each other through mimeographed song books and gatherings at demonstrations. Thus, the music could more easily serve to create solidarity among people than having to carry a message from a central leadership.

Song leaders were either paid organizers, who may have come from outside the community but who were socially similar to community members, or community leaders, especially ministers and teachers. Community meetings were run like church services, which for African American southerners meant extensive congregational singing. Some of the songs, such as the movement's anthem "We Shall Overcome," were converted hymns, while others were stylistically similar to hymns. Many of the songs were so-called "Zipper songs" that could be easily adapted for any situation and which allowed participants to make up verses on the spot. They would typically have a single line repeated several times, followed by a chorus. "Oh Freedom" for example, had several verses made up by demonstrators in Albany, Georgia, including "No more jail house..." and to defy the local sheriff, "No more Pritchett..." each verse ending in "And before I'll be a slave, I'll be buried in my grave, And go home to my Lord and be free" (Carawan and Carawan 1963).

3. Tuning in. Music always involves some sort of tuning in (Schütz 1964). And virtually all social movements that use music are attentive to its ability to create solidarity as well as carry a message (Eyerman and Jamison 1998). But, the social relations within which music is enacted affect the ways in which people are connected to each other and thus what is political about the culture. For the Old Left, politics was first and foremost in the lyrics. So tuning in took the form of frame alignment (Snow et al. 1986; Gamson et al. 1992; Benford and Snow 2000; Johnston and Noakes 2005). People were considered close to each other to the extent that they were "on the same page." Cultural activities were considered successful when they raised people's consciousness. To extend the metaphor of tuning in, resonance was defined in terms of political agreement. In contrast, for the Civil Rights Movement, tuning in was based more on common participation in making music. They were able to achieve what the Old Left had aspired to, creating a singing movement. SNCC organizer Charles Sherrod has described how when he first arrived in Albany, Georgia, people had learned to sing "We Shall Overcome" from seeing it on television, but that it was stiff and passive. So, he taught them how to join arms, sway, and harmonize, binding the participants into a collectivity (Reagon 1975).

4. Embeddedness: Music for the Old Left was embedded in a political party aspiring to change people's consciousness. Their music was overtly political, which in western society creates a tension with aesthetic standards of "pure" culture. When activists became performers, they thus distinguished between their political songs and their popular songs, as the Almanac Singers did when they intentionally balanced their repertoire with political and folk songs (Lieberman 1995). When they tried to embed music in other forms, such as unions, they found little success. They did find a ready

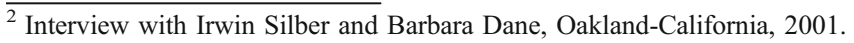


audience when they performed for Progressive candidate Henry Wallace in the 1948 presidential campaign, although the effort bankrupted the sponsoring organization, People's Songs, Inc. For the Civil Rights Movement, the music was embedded in the collective action itself, in meetings, picketing, riding on busses, sitting in, and passing the time in jail. These were activities in which a crowd of people, often confronted with hostile authorities, engaged in drawn out activity that required tight coordination and communal movement. Their repertoire of collective action was ideal for making music together. And music was the ideal medium for reinforcing and empowering these forms of collective action. Tellingly, when the movement abandoned non-violent civil disobedience and its related repertoire of collective action, they also abandoned music in the movement and, like the Old Left before them, embraced music for its content.

\section{Conclusions and the Future of Music in American Social Movements}

Both the Old Left and the Civil Rights Movement were musically successful on their own terms. American folk music developed from a category comprehensible mainly to academics and antiquarians into a mainstream genre. People associated with the folk music project of the 1930s and 1940s created a set of musical codes and a canon of songs that erupted in the 1960s with a new revival. And American folk music, even when divorced from activism, would carry a leftist overtone. The Civil Rights Movement not only ended de jure segregation, its number one goal, but also has offered the template of collective action for all sorts of rights-based movements since then, even those on the right.

The lessons can be extended beyond music. The social relations within which social movement culture is enacted are shaped by both cultural medium and the designs of the activists. For the women's movement of the 1970s, poetry was a major activity in consciousness-raising groups, both its writing and reading. It was a medium for women to articulate problems they had intuitively felt but for which they lacked a language. Women used poetry as a means to communicate with other women in their consciousness-raising group and to collectively connect the personal to the political (Reed 2005). Both music and poetry have a strong metric component, a pre-cognitive tuning in that transcends the literal meaning of the words. By the social process, they were also making the personal collective, taking a medium usually assumed to be the epitome of personal expression and individuality and using it to both capture and deepen the consciousness of a group. Similarly, the Chicano collective creation of murals collectivizes what is usually considered an individualistic medium. Though there is a division of labor between production and consumption of murals, the producers remain part of the public whose space is transformed by the mural.

Thus, examining the social processes by which people do culture can deepen our understanding of how social movements operate. Recent work, such as Polletta's pathbreaking analysis of participatory democracy in movement organizations, has focused on the internal dynamics of how social movement operate, shifting attention away from the perennial issue of why people join. We can move beyond the evangelical model of social movements to see what explains the internal social relationships with movements and how those social relations help shape the broader effects that social movements have on society. The social relations of culture - the division of labor within which culture is enacted, the power dynamics among those doing culture, the way that culture tunes in people involved in culture, and the activities within which culture is enacted - transcend cultural content. The social relations explain the effects of culture on social movement dynamics and 
consequences in a way that analyzing the content of culture inevitably misses. In this paper, music illustrates a general principle that applies similarly to art, drama, poetry, and other aesthetic endeavors.

The conditions for social movements to deeply embed music in their collective action like the Civil Rights Movement are today not propitious. First, most constituents have grown up relating to music almost solely as mass media. Even Christian churches include more performative music and less congregational singing. Children reaching maturity today have had fewer opportunities to participate in music-making than previous generations as schools have cut back on all arts. Thus, music is increasingly something you buy more than something you can imagine participating in.

Secondly, it is unlikely that any culturally coherent group will have the cultural authority to shape any movement's culture independent of the mass media in the way that blacks did in the Civil Rights movement. Beyond the critical core who grew up singing in churches, participants from other cultural backgrounds entered a movement in which the culture of the black church and the black colleges presented a template respected by all. Only ethnically based groups today have a culturally homogeneous leadership that offers a model for doing culture.

Third, there is virtually no cultural infrastructure in current movements - no unifying party such as the communists had, no national organizations like People's Songs, Inc., no record companies like Folkways.

Finally, collective action itself has lost the tradition of doing music. In marches, chants have replaced songs. Demonstrations only occasionally have music, almost always as performance without participation. The songs of an earlier generation are considered old fashioned, and none have taken their place. The web itself can be the institutional basis of new movements if they can be thoroughly integrated into other aspects of life in the same sense that black churches and black colleges were integrated into the lives of many Civil Rights activists.

Yet, there are glimmers of change. New electronic technologies allow music to be made more easily than ever before. All but the very poor and uneducated have the hardware to make music and the means to distribute it broadly. The potential that the web offers for decentralized movements in general equally applies to music and other culture. Especially if we broaden the making of music beyond singing and playing an instrument to include mixing, synthesizing, and sampling, there are new opportunities for movements to do music.

Finally, both of these movements can offer inspiration for activists of the future. And by learning from the history of these movements' social relations as well as their content, they can make their own history that reshapes the world.

Open Access This article is distributed under the terms of the Creative Commons Attribution Noncommercial License which permits any noncommercial use, distribution, and reproduction in any medium, provided the original author(s) and source are credited.

\section{References}

Andrews, K. T., \& Biggs, M. (2006). The dynamics of protest diffusion: movement organizations, social networks, and news media in the 1960 sit-ins. American Sociological Review, 71, 752-777.

Becker, H. S. (1982). Art worlds. Berkeley: University of California Press.

Bell, B. (1975). Folk art and the Harlem renaissance. Phylon, 36, 155-163. 
Benford, R. D., \& Snow, D. A. (2000). Framing processes and social movements: an overview and assessment. Annual Review of Sociology, 26, 611-639.

Berezin, M. (1994). Cultural form and political meaning: state-subsidized theater, ideology, and the language of style in fascist Italy. The American Journal of Sociology, 99, 1237-1286.

Bohlman, P. V. (1999). Ontologies of music. In N. Cook \& M. Everist (Eds.), Rethinking music (pp. 17-34). Oxford: Oxford University Press.

Carawan, G., \& Carawan, C. (1963). We shall overcome: Songs of the southern freedom movement. New York: Oak Publications.

Citron, M. J. (2000). Gender and the musical canon. Urbana: University of Illinois Press.

Cohen, R. D. (2002). Rainbow quest: the folk music revival and American society, 1940-1970. Amherst: University of Massachusetts Press.

Denning, M. (1996). The cultural front: The laboring of American culture in the twentieth century. London: Verso.

DeNora, T. (1995). Beethoven and the construction of genius: Musical politics in Vienna, 1792-1803. Berkeley: University of California Press.

DeNora, T. (2000). Music in everyday life. Cambridge: Cambridge University Press.

DeNora, T. (2002). Music into action: performing gender on the Viennese concert stage, 1790-1810. Poetics, 30, 19-33.

Diani, M., \& McAdam, D. (Eds.). (2003). Social movements and networks: relational approaches to collective action. Oxford: Oxford University Press.

DiMaggio, P. (1982a). Cultural entrepreneurship in nineteenth-century Boston: the creation of an organizational base for high culture in America. Media, Culture and Society, 4, 33-50.

DiMaggio, P. (1982b). Cultural entrepreneurship in nineteenth-century Boston, Part II: the classification and framing of American art. Media, Culture and Society, 4, 303-322.

Du Gay, P. (1997). Doing cultural studies: the story of the Sony walkman. London: Sage.

Eyerman, R., \& Jamison, A. (1998). Music and social movements. Cambridge: Cambridge University Press.

Feld, S. (1984). Sound structure as social structure. Ethnomusicology, 28, 383-409.

Floyd, S. A., Jr. (1990). Black music in the Harlem Renaissance: a collection of essays. New York: Oxford University Press.

Frith, S. (1996). Performing rights: on the value of popular music. Oxford: Oxford University Press.

Gamson, W. A., Croteau, D., Hoynes, W., \& Sasson, T. (1992). Media images and the social construction of reality. Annual Review of Sociology, 18, 373-393.

Gioia, T. (2006). Work songs. Durham: Duke University Press.

Gould, R. V. (1995). Insurgent identities: class, community, and protest in Paris from 1848 to the commune. Chicago: University of Chicago Press.

Ikegami, E. (2005). Bonds of civility: aesthetic networks and the political origins of Japanese culture. Cambridge: Cambridge University Press.

Jasper, J. M. (1998). The emotions of protest: affective and reactive emotions in and around social movements. Sociological Forum, 13, 397-424.

Johnston, H., \& Noakes, J. A. (Eds.). (2005). Frames of protest: social movements and the framing perspective framing American politics. Lanham: Rowman and Littlefield.

Klandermans, B., \& Oegema, D. (1987). Potentials, networks, motivations, and barriers: steps towards participation in social movements. American Sociological Review, 52, 519-531.

Leblanc, L. (1999). Pretty in punk: girls' gender resistance in a boys' subculture. New Brunswick: Rutgers University Press.

Lieberman, R. (1995). "My song is my weapon": People's songs, American communism, and the politics of culture, 1930-1950. Urbana: University of Illinois Press.

Lomax, A. (1962). Song structure and social structure. Ethnology, 1, 1-27.

Martin, B. D. (2004). The theater is in the street: politics and performance in sixties America. Amherst: University of Massachusetts Press.

Marwell, G., Oliver, P. E., \& Prahl, R. (1988). Social networks and collective action: a theory of the critical mass, III. American Journal of Sociology, 94, 502-534.

McNeill, W. H. (1995). Keeping together in time: dance and drill in human history. Cambridge: Harvard University Press.

Pedriana, N., \& Stryker, R. (1997). Political culture wars 1960s style: equal employment opportunityaffirmative action law and the Philadelphia plan. American Journal of Sociology, 103, 633-691.

Reagon, B. J. (1975). Songs of the civil rights movement, 1955-1965: a study in culture history, PhD Dissertation, Howard University.

Reed, T. V. (2005). The art of protest: culture and activism from the civil rights movement to the streets of Seattle. Minneapolis: University of Minnesota Press. 
Rosenthal, R., \& Flacks, R. (2009). Music and social movements. New York: Paradigm Publisher.

Roussel, V. (2007). Occupational logics and political commitment: American artists against the Iraq war. International Political Sociology, 1, 373-390.

Schütz, A. (1964). Making music together. Studies in social theory (pp. 157-178). The Hague: Nijhoff.

Seeger, P. (1992). In J. M. Schwartz (Ed.), The incompleat folksinger. Lincoln: University of Nebraska Press.

Seeger, A. (2004). Why Suyá sing: a musical anthropology of an Amazonian people. Urbana: University of Illinois Press.

Small, C. (1998). Musicking: the meanings of performing and listening. Hanover: Wesleyan University Press.

Snow, D. A., Rochford, E. B., Jr., Warden, S., \& Benford, R. D. (1986). Frame alignment processes, micromobilization, and movement participation. American Sociological Review, 51, 464-481.

Snow, D. A., Zurcher, L. A., Jr., \& Ekland-Olson, S. (1980). Social networks and social movements: a microstructural approach to differential recruitment. American Sociological Review, 45, 787-801.

Stepan-Norris, J., \& Zeitlin, M. (1989). 'Who gets the bird?' or, how the communists won power and trust in America's unions: the relative autonomy of intraclass political struggles. American Sociological Review, $54,503-523$.

Swidler, A. (1995). Cultural power and social movements. In H. Johnston \& B. Klandermans (Eds.), Social movements and culture (pp. 25-40). Minneapolis: University of Minnesota Press.

Taylor, T. D. (2007). Beyond exoticism: western music and the world. Durham: Duke University Press.

Tilly, C. (2005). Trust and rule. Cambridge: Cambridge University Press.

Waters, S. (2003). Social movements in France: towards a new citizenship. Basingstoke: Palgrave Macmillan.

Weber, W. (1999). The history of the musical canon. In N. Cook \& M. Everist (Eds.), Rethinking music (pp. 336-355). Oxford: Oxford University Press.

White, H. C., \& White, C. A. (1993). Canvases and careers: institutional change in the French painting world. Chicago: University of Chicago Press.

Zolberg, V. L. (1990). Constructing a sociology of the arts. Cambridge: Cambridge University Press.

Zolberg, V. L., \& Cherbo, J. M. (Eds.). (1997). Outsider art: contesting boundaries in contemporary culture. Cambridge: Cambridge University Press. 